\title{
ARCHEOLOGICKÝ VÝZKUM BOJIŠŤ A VOJENSTVÍ RANÉHO NOVOVĚKU V ČESKÝCH ZEMÍCH. HISTORIE, STAV POZNÁNÍ, DISKUSE
}

\author{
VÁCLAV MATOUŠEK
}

\begin{abstract}
Abstrakt: Cílem príspěvku je pokus o shrnutí a hodnoceni dosavadního vývoje archeologického zájmu o novověká bojiště a novověké vojenství na územi České republiky. Chronologický rámec prehledu vychází $z$ aktuálního, historického vymezení novověku do širokého rozpétí od 2. poloviny 15.-16. století do 2. poloviny 18. až prvých desetiletí 19. století. Historii archeologického studia novověkého vojenství můžeme sledovat od počátku 20. století. Od samého počátku je výzkum zaměren přednostně na bojiště a relikty polních vojenských opevnění. Zpočátku se jednalo o jednorázové izolované výzkumy. Od 80. let 20. století probíhají též dlouhodobé, systematické a široce mezioborově koncipované projekty. K rozvoji výzkumu v poslednich letech významně prispívají aplikace modernich technologii: letecké snímkování, laserové skenování zemského povrchu a prospekce pomoci detektori̊ kovi̊.
\end{abstract}

Kličová slova: archeologie vojenství-novověk - české zemé.

Archaeological Research into Battlefields and Military Action in the Czech Lands in the Early Modern Age. History, state of knowledge, discussion

Abstract: The objective of this article is to summarise and assess the development of archaeological interest in modern-age battlefields and military action in the territory of the present-day Czech Republic. The chronological framework of the overview is rooted in the current historical definition of the modern age, from the second half of the 15th-16th century until the second half of the 18th-first decades of the 19th century. History of the archaeological study of modern-age military action goes back to the early 20 th century. Since the onset, research has primarily focused on battlefields and remains of field fortifications. First, there were only isolated investigations; long-term, systematic interdisciplinary research projects have been conducted since the 1980s. The development of research in recent years has been contributed to by modern technologies: aerial photography, laser scanning of the surface of the ground and prospecting with metal detectors.

Key words: military archaeology - modern age - Czech lands.

\section{Smysl a cíle předloženého textu}

V průběhu více než sta let postupného vývoje archeologického výzkumu období mladších českých dějin se postupně vyprofilovalo několik tematických okruhů zvýšeného archeologického zájmu. Jedním z nich je již od počátku výzkum novověkých bojišt' (k vývoji archeologického výzkumu novověku v českých zemích obecně naposledy Matoušek 2011; Žegklitz 2013; Matoušek 2015). Smyslem i cílem předloženého textu je pokusit se nastínit dosavadní vývoj archeologického zájmu o novověká bojiště a novověké vojenství u nás. Dále se pokusím tento vývoj shrnout, charakterizovat a otevřít diskusi o jeho dalších perspektivách.

\section{Chronologické a tematické vymezení předmětu zájmu, základní pojmy}

Počátek novověku je dnes kladen do širokého rámce druhé poloviny 15. až 16. století. Závěr novověku je kladen do širšího intervalu druhé poloviny 18. až prvých desetiletí 19. století (stručně např. Hroch 2005, 216-217). Z hlediska dějin vojenství lze řadit do novověku na našem území v 17. století zejména vpád pasovských 1611 do Čech, třicetiletou válku 1618-1648, v 18. století válku o dědictví rakouské 1740-1748, sedmiletou válku 1756-1763, válku o bavorské dědictví 1778-1779 a na přelomu 18. a 19. století války napoleonské 1796-1815. Dále je třeba připomenout, že na konci 16. a v druhé polovině 17. století zasáhly Moravu turecké války. Opomenuta by neměla být ani ozbrojená stř̌etnutí armády a vzbouřených sedláků při povstáních v letech 1680 , 1693 a 1775 (srov. Procházka a kol. 1986 nebo Pernes a kol. 2003).

$\mathrm{Z}$ dílčích témat charakterizuje novověké vojenství například rozvoj bastionového stavitelství (jak stálého, tak dočasného polního), dále rozvoj dělostřelectva a ručních palných zbraní, 
organizační vývoj od zemské hotovosti přes žoldnéřskou armádu až ke stálé státní armádě. Nebo vývoj od variabilní výzbroje a výstroje k uniformitě, a řada dalších témat. Mnohé z výše uvedených válečných událostí, ozbrojených střetnutí i dílčích aspektů vývoje vojenství v českých zemích v novověku se v archeologických pramenech již zřetelně projevily (např. studium bastionového stavitelství, rozvoj dělostřelectva a ručních palných zbraní, prostorové analýzy bojišt'). Další jsou pojednávány dosud v menší míře (vojenské hroby a hřbitovy). U ostatních můžeme s vysokou pravděpodobností jejich odraz v archeologických pramenech očekávat (např. vývoj od variabilní výzbroje a výstroje k uniformitě, studium kasáren, vojenských cvičišt' apod.).

V domácí a hlavně zahraniční odborné literatuře je možné se setkat s řadou pojmů, jejichž náplň se často překrývá: nejčastěji battlefield archaeology, military archaeology, conflict archaeology, archaeology of violence. Při studiu pravěku i středověku má zmíněná variabilita pojmů nepochybně své opodstatnění. V souvislostech evropské a americké novověké civilizace je však již možné a domnívám se, že i potřebné rozlišovat mezi jakýmkoliv násilím a konfliktem na straně jedné a střetem pravidelných armád na straně druhé. Rovněž je možné a potřebné rozlišovat mezi společností a kulturou civilní a vojenskou. $Z$ těchto důvodů budu v dalším textu používat jen pojem archeologie vojenství, resp. military archaeology. S ohledem na níže nastíněný přehled dosavadního vývoje výzkumu má opodstatnění i pojem archeologie bojišt', resp. battlefield archaeology.

\section{Stručný nástin historie archeologického výzkumu novověkého vojenství na území České republiky}

Zatím nejstarší známý terénní výzkum novověkého bojiště u nás proběhl u Rakovníka (Renner 1912). Předmětem studia bylo bojiště z roku 1620. Na počátku 30. let provedli členové muzejního spolku v Brandýse nad Labem výzkum části opevnění švédského tábora u Staré Boleslavi (Zuman 1931). V následujících desetiletích se uskutečnily další dílčí výzkumy různé povahy. Např́klad ve 40. letech byla zahájena povrchová terénní dokumentace novověkých opevnění na slezsko-uhersko-polské hranici (podrobně Krůl 2010; 2013). V roce 1957 byl v Sulejovicích odkryt hrob vojáka patrně z bitvy u Lovosic 1756 (Buchvaldek 1999, 82). V 50.-70. letech proběhlo na bojišti na Bílé hoře postupně několik záchranných výzkumů, jejichž předmětem byly hromadné hroby, možná jen jeden rozsáhlý hromadný hrob z roku 1620 (Janská 1966; Smetánka 1967; Havel 1980). V Hradci Králové provedl v roce 1973 dva výzkumy novověkého městského pevnění J. Sigl (1978, 59-60). Na počátku 70. let provedli Z. Smetánka a J. Richterová výzkum zaniklé vsi Německá Lhota na Kladensku, která zanikla v souvislosti s třicetiletou válkou (Richterová 1981; 1982).

Kvalitativní posun v archeologickém výzkumu novověkých bojišt' přinesla série dlouhodobých systematických, interdisciplinárních výzkumů zahájená na počátku 80. let. Prvým z nich byl v letech 1980-1984 výzkum bojiště z roku 1759 v Nebesích u Aše (Matoušek a kol. 1990). Od roku 1988 probíhá s přestávkami až do současnosti výzkum bojiště z roku 1647 pod hradem Třebelí na Tachovsku (Matoušek 2006). Od roku 2005 probíhá systematický výzkum soustavy polních opevnění na slezsko-uhersko-polské hranici (Krůl 2010; 2013; naposledy Krůl 2015). Od roku 2006 probíhá s přestávkami systematický výzkum bojiště z roku 1621 mezi Rozvadovem a Waidhausem (Altová a kol. 2008; Matoušek 2011a; Matoušek 2013; Preusz a kol. v tisku). Od roku 2010 probíhá systematický výzkum bojiště z roku 1620 u Rakovníka (Blažková 2011).

Zvláštním projektem je systematická interdisciplinární analýza rytin bojišt' třicetileté války v českých zemích založená na kombinaci studia písemných, ikonografických a kartografických pramenů s archeologickým výzkumem, resp. na kombinaci metod historického, terénního/ archeologického, kartografického, geodetického studia a metod dějin umění a environmentálních dějin (předběžná shrnující zpráva o výsledcích projektu in Matoušek-Blažková 2012).

Kromě toho proběhla nebo dosud probíhá řada dalších výzkumů založených na kombinaci menšího počtu pramenů a metod. Př́ikladem může být detektorový průzkum na Volarských šancích na Šumavě z období stavovského povstání (Beneš-Kubů-Török 1995) nebo detekto- 
rový průzkum již zmíněného švédského tábora u Staré Boleslavi z let 1639/1640 (Waldhauser 2009). Značné pozornosti se těší již od počátku 20. století více či méně rozsáhlé soustavy polních opevnění. Původně byly zkoumány pouze na základě kombinace písemných pramenů a terénního průzkumu. Př́íkladem může být již zmíněné bojiště u Rakovníka 1620 (Renner 1912), nebo bojiště u Zahájí 1742 (Kubů-Zavřel 1988). Další variantou je kombinace terénního povrchového průzkumu se studiem písemných a kartografických pramenů. Př́ikladem je studium opevnění z války o dědictví bavorské v severních Čechách (Nejman 2010), války sedmileté a války o dědictví bavorské ve východních Čechách (Čížek-Slavík 2010) nebo války o dědictví bavorské na Vrchlabsku (Hájková-Louda 2013). Dosud ojedinělým počinem je snaha o interpretaci náhodného nálezu opevnění na základě dobové rytiny (Daňhel 2008). K vyhledávání a dokumentaci polních opevnění v posledních desetiletích významně přispívá technický vývoj. Příkladem geodetického zaměření a následné 3D vizualizace může být obléhací švédský obléhací tábor nad hradem Kynžvartem ve Slavkovském lese z roku 1647/1648 (Kovandová-Matoušek 2004). Běžná je prospekce a dokumentace formou leteckého snímkování. Př́íkladem je interdisciplinární studium opevnění z roku 1813 mezi Budyní a Postoloprty (Smrž-Hluštík 2007). A také prospekce a dokumentace laserovým skenováním (Gojda 2013). Zaniklá opevnění jsou vyhledávána v terénu i na kartografických pramenech také pomocí počítačových geografických informačních systémů (GIS; Neuvirtová 2010). Kombinaci archeologické sondáže, povrchové prospekce, leteckého a laserového snímkování a studia kartografických pramenů využivá systematický výzkum linie opevnění z války o bavorské dědictví mezi Třemi Bubny a Jaroměří (Hejhal-Horník 2015).

Paralelně s dlouhodobými koncepčními projekty probíhají stále jednorázové akce formou záchranných a předstihových výzkumů. Např́íklad v roce 1993 byl dokumentován př́ikop u Tvarožné na Moravě, který snad souvisí s pruským opevněním z roku 1742 (Čižmář-GeislerováUnger 2000, 80). V roce 1994 byla v Brně na úpatí vrchu Špilberku dokumentována část obléhacího švédského př́kopu z roku 1645 (Loskotová-Hanák 1995).

Série výzkumů se týká také bitev napoleonských válek na našem území, resp. nálezů hrobů z bitvy u Slavkova 1805 (Horáčková-Benešová 1997; Horáčková-Vargová 1999; BohunováUnger 1999; Čižmář-Geislerová-Unger 2000), bitvy u Znojma 1809 (Kovárník a kol. 2006) a u Loun 1813 (Smrž 2012).

Z řady výzkumů novověkých opevnění a bojišt' se vymyká výzkum cihelny, která dodávala materiál pro stavbu josefovské pevnosti. Výzkum prováděl v letech 2003-2004 J. Sigl v Jaroměři (Bláha-Sigl 2007). Pokračuje rovněž výzkum vesnických sídel zaniklých v průběhu třicetileté války (Vařreka a kol. 2006; Vařeka 2009; 2014; Kodera 2009; Symonds-Vařeka 2016). ${ }^{1}$

\section{Pokus o shrnutí a charakteristiku dosavadního vývoje výzkumu}

Výsledky více než sta let spontánního vývoje archeologického zájmu o problematiku novověkého vojenství v českých zemích je možné členit do několika skupin. Metodicky nejpropracovanější je zatím projekt systematického široce mezioborově založeného studia rytin událostí třicetileté války v českých zemích v díle M. Meriana (Matoušek-Blažková 2012). Projekt testuje hypotézu, podle níž jsou batailistické rytiny v dílech Theatrum Europaeum a Topographia Bohemiae, Moraviae et Silesiae jedinečným a mnohovrstevným pramenem nejen k poznání válečných událostí a krajin, $\mathrm{v}$ nichž se odehrávaly. Jsou zároveň i cenným pramenem $\mathrm{k}$ dějinám kartografie a dějinám umění. V neposlední řadě jsou též významným pramenem k dějinám mentalit, nebot' jejich důkladná mezioborová analýza umožňuje nahlédnout do způsobů recepce válečných událostí a krajiny a poznávat postupy konstrukce jejich obrazů. Metodika mezioborové analýzy je postupně rozpracovávána na př́kladech studia konkrétních rytin - např. Matoušek a kol. 2007; Altová a kol. 2007; Matoušek-Zimová-Janata 2012; Janata-Matoušek-Zimová 2013; Janata-Matoušek-Zimová 2016).

Podobně široce interdisciplinárně byly, resp. jsou založeny i projekty systematického zkoumání bojišt' třicetileté války u Rozvadova, Rakovníka a Třebele a bojiště sedmileté války

1 Vyčerpávající přehled archeologických výzkumů středověkých a novověkých bojišt' na našem území podali před časem Grabolle a kol. 2009. 
u Nebes. Vzhledem k celkovému rozsahu jednotlivých novověkých bojišt' mají ovšem tyto projekty primárně jen charakter dílčích, více či méně cílených, prostorově omezených sondáží. Terénní výzkumy bývají zpravidla vázány na výrazné relikty polních opevnění. Při těchto systematických projektech se v maximální míře uplatňuje kombinace studia písemných, ikonografických a kartografických pramenů s povrchovým terénním průzkumem, archeologickými sondážemi, detektorovým průzkumem, leteckým snímkováním, laserovým skenováním povrchu i 3D modelováním bojiště. V ojedinělých př́ípadech je tato kombinace doplněna i archeologickým experimentem (Matoušek 2004; 2006a; Dragoun-Matoušek-Tuček 2007) nebo studiem lidových pověstí (Mevaldová 1990; Hornofová 2002). V průběhu těchto výzkumů se postupně vytváří i ucelené soustavy navzájem propojených metod. Př́íkladem je cílená úzká vazba detektorového průzkumu na analýzu munice, resp. palných zbraní a analýzu chování vojenských jednotek na bojišti, kombinovaná s písemnými a ikonografickými prameny. Nejvýraznějších výsledků zatím bylo v tomto směru dosaženo na bojištích u Rozvadova a u Rakovníka.

Dalším relativně samostatným tematickým okruhem studia novověkých bojišt', zejména bojišt' třicetileté války, jsou otázky polního vojenského stavitelství. Konkrétně morfologie opevnění, jejich konstrukce a problematika jejich archeologizace (k tomu souhrnně Matoušek 2013a; 2015 b; 2017). V této souvislosti je třeba připomenout potřebu systematické kombinace archeologického terénního studia se studiem písemných pramenů, zejména vojenských př́ruček (srov. Meduna 1990; Dragoun-Matoušek-Tuček 2007; Grof 2010). Vhodným doplňkem studia jsou experimentální stavby zkoumaných opevnění (literatura viz výše).

Zvláštní pozornost zasluhují projekty systematického vyhledávání a dokumentace rozsáhlých soustav polních opevnění z 18. a počátku 19. století. Lze na ně nahlížet jako na specifické aktivity (archeologické) památkové péče. Ale také jako na důležitý příspěvek ke studiu vojensko politických událostí novověkých dějin (srov. např. Mertlík 2013). O významu, jaký archeologická i historická obec přikládá studiu reliktů polních opevnění, svědčí i série specializovaných odborných setkání (Slavík ed. 2010; Kuprová-Buroň edd. 2013; Šmejda ed. 2015).

Počínaje 80 . lety 20 . století se $\mathrm{v}$ zahraničí prosazuje jako mimořádně důležitá metoda terénního studia historických bojišt' systematický průzkum pomocí detektorů kovů. ${ }^{2} \mathrm{~V}$ českých zemích je tato metoda také využívána a přináší někdy i velmi zajímavé výsledky (srov. BenešKubů-Török 1995 nebo Waldhauser 2009). K systematickému řešení koncepčních otázek studia historických bojišt' (upřesnění míst bojů, poznání charakteru střetů, poznání výzbroje) byly detektory kovů aplikovány ovšem zatím pouze na bojištích u Rakovníka z roku 1620 a Rozvadova z roku 1621 (viz výše).

\section{Stručný pokus o srovnání domácího výzkumu se stavem studia v zahraničí}

Archeologie vojenství, zejména archeologický výzkum historických bojišt' je - zvláště v posledních třech či čtyřech desetiletích - neobyčejně dynamickou a možno říci také velmi populární archeologickou disciplínou doslova na celém světě (srov. např. Scott-Babits-Haecker 2007; Meller 2009; Meller-Schefzik 2015). Potřebné srovnání domácího vývoje oboru s vývojem zahraničním proto na prvém místě komplikuje téměř nepřehledné množství výzkumů, odborných setkání a publikací, jejichž vyčerpávající reflexe již dávno přesahuje síly jednotlivce. Dalším komplikujícím faktorem je odlišná tradice výzkumu v jednotlivých zemích a v neposlední řadě i odlišný historický vývoj jednotlivých regionů, v nichž výzkum probíhá. Názorně lze tyto skutečnosti demonstrovat na př́íkladu komparativní studie A. Homanna (2013), která se soustředí na přehled stavu archeologie bojišt' pouze v relativně malém prostoru střední Evropy. ${ }^{3}$

Z Homannova textu především vyplývá, že dosažený stav archeologického studia novověkého vojenství v českých zemích za vývojem v našem blízkém evropském sousedství nikterak

\footnotetext{
$2 \mathrm{O}$ tom, jaký význam přisuzují někteři badatelé této metodě, svědčí například slova H. Mellera, který neváhá určit jako datum zrodu systematického archeologického výzkumu bojišt' rok 1984, kdy byl zahájen detektorový průzkum bojiště u Little Big Hornu: „Die moderne systematische Schlachtfeldarchäologie ist auf das Engste mit der Entwicklung von Mettaldetektoren verbunden“ (Meller 2011, 98). Srov. též: „,(..) use of metal detectors is the only viable method for locating battle relics in a timely and effective manner" (Homann 2013, 210).

3 „Střední Evropa“ představuje podle N. Mehlerové (2013, Fig. 1), autorky sborníku, v němž je studie A. Homanna zařazena, specifický geografický prostor, který zahrnuje Švýcarsko, Německo, Českou republiku, Polsko, Rakousko, Slovinsko, Slovensko a Mad’arsko.
} 
nezaostává. S výzkumem v německých zemích nás spojuje velké množství výzkumů lokalit z období třicetileté války. Na našem území však dosud nebyl proveden žádný systematický výzkum hromadného hrobu z tohoto válečného konfliktu. Hromadné hroby zkoumané na bojištích v Lützenu (1632), Wittstocku (1636) nebo Alerheimu (1645) patří v posledních desetiletích k nejvýznamnějším zdrojům poznatků o třicetileté válce na německém území (naposledy FriederichSchröder 2015; Nicklisch a kol. 2015). Pro výzkum v českých zemích je naopak charakteristický důraz na studium polních opevnění. Ve srovnání se stavem výzkumu jak v Německu, tak v Polsku (o výzkumu na Britských ostrovech nebo v USA nemluvě) však archeologický výzkum v českých zemích zaostává v rozsahu využivání detektorů kovů při identifikaci historických bojišt' a jejich systematických analýzách.

Dále je možné připomenout, že i na obor archeologie novověkého vojenství u nás je možné vztáhnout postřeh N. Mehlerové (2013), že teorie archeologie novověku v zemích východní Evropy je dosud stále na relativně nízké úrovni. Proto se u nás ani při archeologickém studiu historického vojenství dosud nesetkáváme s vyhraněnými metodickými a metodologickými přístupy. Situace v zahraničí je v tomto smyslu poněkud odlišná. Hojně se můžeme setkat s př́stupem, který bychom mohli nazvat zjednodušeně antropologický. Boj a válka jsou v tomto smyslu chápány jako specifické projevy vnitrodruhové agrese. Archeolog zkoumá relikty tohoto chování a provádí jejich analýzy, aniž by přitom bral zvláštní ohled na historické souvislosti studovaných archeologických pramenů (srov. napr. Scott-Babits-Haecker edd. 2007; Meller ed. 2009; Meller-Schefzik edd. 2015). Opakem tohoto př́ístupu je monografie věnovaná francouzským a indiánským válkám v Severní Americe v letech 1750-1765 (Babits-Gandulla 2015). Autoři důsledně kombinují písemné, ikonografické, kartografické a archeologické prameny, a vytvářejí tak ucelený komplexní obraz jednoho válečného konfliktu. Obdobně komplexní charakter má rovněž monografie T. Pollarda o bitvě u Culloden Moor z roku 1746 (Pollard 2012).

Úzké vazby archeologického a historického studia jsou charakteristické i pro archeologii vojenství v českých zemích (srov. projekty studia bojišt' u Rakovníka, Třebele a Nebes nebo systematické studium Jablunkovských šancí a projekt komplexní analýzy rytin válečných událostí třicetileté války i mezioborové konference na téma novověkých opevnění - literaturu viz výše). Výrazné příklady „antropologického“ přístupu z našeho prostředí dosud známy nejsou. Nepřehlédnutelný je naopak u nás trend studovat polní opevnění primárně jako specifické prvky kulturní krajiny a evidovat a analyzovat je metodami krajinné a prostorové archeologie, historické geografie a památkové péče, tj. interpretovat relikty fortifikací jako specifické historické „,reliéfní tvary““ (např. Kuna 2004, 271-274; 2014, 19-21; Neuvirtová 2010; Matoušek 2010, 253-263; Gojda 2013).

\section{Několik závěrečných poznámek k perspektivám archeologického výzkumu novověku v českých zemích}

Archeologie vojenství raného novověku má v českých zemích dlouhou a bohatou tradici a velký badatelský potenciál do budoucna. Přesto však nelze prrehlédnout několik okolností, které naznačují, že by si tento obor již opět zasloužil posun na další, vyšší kvalitativní úroveň, podobně jako tomu bylo v 80 . a 90 . letech 20 . století.

Především je zjevné, že obor archeologie vojenství raného novověku (stejně jako celý obor archeologie novověku, resp. postmedievální archeologie) u nás existuje stále v podstatě jen latentně. Proběhly a stále probíhají sice desítky terénních výzkumů, pořádají se specializovaná odborná setkání, vycházejí specializované publikace, ovšem aktéry tohoto dění nejsou - až na výjimky - specialisté z oboru archeologie novověku nebo instituce specializované na archeologii novověku. Aktéry výzkumu jsou v naprosté většině jednotlivci a instituce, které se kromě jiného věnují, často jen př́ležitostně, také archeologickému studiu novověku. Většinou se jedná o specialisty z oboru archeologie středověku. Hojně užívaný pojem postmedievální archeologie

4 Autorka ovšem používá pojem ,historická archeologie“, který se do značné míry s našimi pojmy archeologie novověku a postmedievální archeologie překrývá. 
proto lze u nás s jistou nadsázkou interpretovat jako projev zájmu badatelů v oboru archeologie středověku o následný kulturně historický vývoj. V důsledku toho je do značné míry stále platný téměř čtvrtstoletí starý postřeh moravského etnologa, historika a archeologa J. Pajera: „Zkoumáni novověkého období pomoci archeologických metod má v dnešní době spišse náhodný a nesoustavný charakter" (Pajer 1990, 26).

Klíčovým předpokladem pro povýšení archeologie novověkého vojenství (resp. též archeologie novověku) na vyšší kvalitativní úroveň je proto (dle mého názoru) její institucionální ukotvení. Předobrazem interdisciplinárního pracoviště pro komplexní studium novověké společnosti a kultury by mohlo být Centrum medievistických studií UK a AV ČR. ${ }^{5}$ Pokud bychom se spokojili jen s pracovištěm specializovaným na archeologii vojenství, inspirací by mohlo být např́ḱklad Center for Historic and Military Archaeology Univerzity v Heidelbergu ${ }^{6}$ nebo Centre for Battlefield archaeology Univerzity v Glasgowě, které vydává i specializovaný časopis Journal of Conflict Archaeology.

Po naplnění tohoto předpokladu by mohly interdisciplinární týmy specialistů na studium novověkého vojenství rozšíriit dosud probíhající projekty systematického studia z problematiky první poloviny 17 . století i na témata $\mathrm{z}$ období 18 . století a napoleonských válek $\mathrm{z}$ přelomu 18. a 19. století. Systematická a koncepční práce týmů archeologů a historiků by se mohla zaměřit na důležitá, ale dosud jen okrajově zkoumaná témata: vojenské příručky, plány a mapy z celého období novověku apod. Důkladného rozpracování by se mohlo dočkat téma vývoje polního a stálého vojenského stavitelství. Dosud se jedná o téma na pomezí archeologie vojenství, krajinné archeologie a památkové péče. Potenciálně se do projektu mohou zapojit badatelé z oboru dějin vojenství, historické kartografie, resp. historické geografie, geodézie, kartografie a dějin umění.

Oficiální institucionální základna by byla nepochybně příznivým předpokladem i pro rozvoj systematických průzkumů pomocí detektorů kovů. Jak ukazují zkušenosti domácí i zahraniční, skutečně efektivní detektorový průzkum vyžaduje dlouhodobé nasazení relativně velkého množství pracovníků a jejich pečlivou koordinaci (srov. např. Šámal 2011; Hrnčiřík 2013). Finanční náklady na provádění detektorových průzkumů nebývají vysoké. Nároky na logistické zabezpečení průzkumu však bývají značné: zahrnují pečlivou přípravu, důslednou koordinaci a kontrolu terénních prací i neméně pečlivé vyhodnocení týmem, který tvoří přinejmenším konzervátor, badatel v oboru historie vojenství a specialista na geoinformační systémy. Dosavadní praxe, kdy všechny naznačené práce vykonává sám archeolog, je sice záslužná a obdivuhodná, ovšem také velmi náročná a $\mathrm{z}$ hlediska efektivity značně problematická.

Institucionální podpora by byla vítána i v př́ípadě intenzivního využívání metod experimentální archeologie. Ojedinělé př́ípady aplikace těchto metod se u nás zatím omezily pouze na rekonstrukci stavby polního opevnění ze třicetileté války z bojiště u Třebele z roku 1647 a ilustrace k monografii o výzkumu tohoto bojiště (Matoušek 2006). Podobně využil T. Pollard snímky z rekonstrukce bitvy v monografii o výzkumu bojiště u Culloden Moor (2009). V této souvislosti je třeba připomenout dosud zcela ojedinělý pokus o experimentální rekonstrukci bitvy u Jankova z roku 1645 provedený a publikovaný amatérským sdružením Mortaigne regiment. ${ }^{8} \mathrm{Je}$ škoda, že aktivity této a dalších skupin se s aktivitami archeologického výzkumu novověkého vojenství dosud míjejí. Kromě staveb polních opevnění a rekonstrukcí bitevních akcí by bylo možné zaměřit spolupráci např́iklad na problematiku palných zbraní (dostřel, ničivý účinek), na studium každodennosti polních vojsk apod.

Další výzvou do budoucna je téma dopadů válečných událostí na civilní obyvatelstvo, sídlištní strukturu a kulturní krajinu. Toto téma je dlouhodobě zpracováváno historiky. ${ }^{9}$ Archeologickým pramenům $\mathrm{k}$ dopadům událostí třicetileté války na venkovskou krajinu se soustavně věnuje zatím jen archeologický tým Západočeské univerzity v Plzni. Téma je opět doslova jako

\footnotetext{
5 Podrobně na www.cms.flu.cas.cz.

6 Viz www.heidelberg.edu/offices/center-historic-and-military-archaeology.

7 Viz www.gla.ac.uk/schools/humanities/research/archaeologyresearch/battlefieldarchaeology.

8 Více o tomto sdružení na www.mortaigne.com.

9 Naposledy u nás na konferenci „Venkov, rolník a válka ve střední Evropě novověku. Od třicetileté války do války studené“, Národní zemědělské muzeum - Univerzita Karlova, 13.-14. 10. 2016.
} 
stvořené pro široce založenou mezioborovou spolupráci přinejmenším z oborů historiografie, archeologie, etnologie, environmentálních dějin a krajinné/environmentální archeologie.

Je pravděpodobně jen otázkou času, kdy bude na některém novověkém bojišti v českých zemích odkryt hromadný hrob takových rozměrů, jako jsou hroby nalezené v posledních letech na německých bojištích třicetileté války (Lützen, Wittstock, Alerheim - shrnuje Homann 2013, 217-220). Komplexní studium pramene tohoto druhu je opět úkol, který daleko přesahuje entuziasmus jednotlivce.

Lze samozřejmě jen spekulovat, kdy (a zda vůbec) vznikne u nás instituce specializující se na archeologický výzkum novověku, nebo pouze na archeologický výzkum novověkého vojenství. Do té doby bude třeba nadále spoléhat na entuziasmus jednotlivců nebo malých, ad hoc utvářených společenství. Výsledky dosavadního, více než sto let trvajícího výzkumu však naznačují, že ani tato perspektiva nemusí být zcela beznadějná.

Tato studie vznikla v rámci projektu „Proměněná země: interdisciplinární výzkum vlivu třicetileté války na venkovskou krajinu Čech“, GAČR 15-03380S.

\section{Prameny a literatura}

ALTOVÁ, B. a kol., 2007: Altová, B.-Alt, J.-Matoušek, V.-Šimek, J., Krajinná panoramata bitvy u Jankova v Theatru Europaeu - Die Landschftspanoramen einer Schlacht bei Jankov in dem Theatrum Europaeum, AVČ 11, 589-633.

ALTOVÁ, B. a kol., 2008: Altová, B.-Kössl, A.-Matoušek, V.-Procházka, Z.-Šimek, J., Tzv. Tillyho šance u Rozvadova ve světle terénní dokumentace a ikonografických pramenů, předběžná zpráva - Die sogenannten Tilly-Schanzen bei Rosshaupt (Rozvadov) im Licht der Terraindokumentation sowie der ikonographischen und kartographischen Quellen, Landkreis Tachau (Tachov), Westböhmen. In: Archeologické výzkumy v severozápadních Čechách v letech 2003-2007. Sborník k životnímu jubileu Zdeňka Smrže (Černá, E.-Kuljavceva-Hlavová, J., edd.), 359-374. Most.

BABITS, L. E.-GANDULLA, S., 2015: The Archaeology of French and Indian War Frontier Forts. University Press of Florida.

BENEŠ, J.-KUBŮ, F.-TÖRÖK, J., 1995: Soubor militarií z počátku třicetileté války z Volarských šancí - Die an den Wallerer Schanzen gefundene Militarienkollektion aus dem Anfang des Dreissigjährigen Krieges, AR XLVII, 461-480.

BLAŽKOVÁ, K., ed., 2011: Bitva u Rakovníka 1620. Rakovník.

BLÁHA, R.-SIGL, J,. 2007: Archaeological excavation of a Modern period brickworks on the Kimberly Clark site in Jaroměr. In: Studies in Post-Mediaeval Archeology 2, 137-144. Praha.

BOHUNOVÁ, M.-UNGER, J., 1999: Graves of Soldiers of the Battle of Austerlitz 1805, Osteoarchaeology of the Napoleonic Battlefields, Abstracts of the 1st International Conference. Camerino, Tolentino, Pollenza: Universita degli Studi di Camerino, Facolta di Scienze Matematiche Fisiche e Naturali, Associazione Antropologica Italiana, 2.

BUCHVALDEK, M., 1999: Slovanské pohřebiště v Sulejovicích, okr. Litoměřice - Slawische Gräberfeld in Sulejovice, Kr. Litoměřice, Studia Mediaevalia Pragensia 4, 81-116.

ČIŽMÁŘ, M.-GEISLEROVÁ, K.-UNGER, J., edd., 2000: Výzkumy 1993-1998. Brno.

ČÍŽEK, J.-SLAVÍK, J., 2010: Zemní opevnění z 18. století ve východních Čechách. In: Polní opevnění od trricetileté války do roku 1945. Monumentae vivent (Slavík, J., ed.), 37-44. Jaroměř - Josefov.

DAŇHEL, M., 2008: Archeologické zjištění vojenského tábora z tř̌icetileté války u Křenova (okr. Přerov), Střední Morava 27, 49-64.

DRAGOUN, B.-MATOUŠEK, V.-TUČEK, J., 2007: Experimentální stavba modelu polního opevnění ze třicetileté války v Uhř́nově, (Re)konstrukce a experiment v archeologii. Živá archeologie 8, 61-66.

FRIEDERICH, S.-SCHRÖDER, O., 2015: Das Massengrab von Lützen. In: Krieg. Eine archäologische Spurensuche (Meller, H.-Schefzik, M., edd.), 399-404. Halle (Saale).

GOJDA, M., 2013: Výzkum, dokumentace a mapování novověkých polních opevnění prostřednictvím letecké prospekce, fotografie a laserového skenování - Identification, documentation and mapping historical field defensive features through aerial reconnaissance, photography and airborne laser scanning. In: Archeologie a letecké laserové skenování země - Archaeology and airborne laser scanning of the landscape (Gojda, M.-John, J., edd.), 38-49. Plzeň. 
GRABOLLE, R. a kol., 2009: Grabolle, R.-Matoušek, V.-Meduna, P.-Smrž, Z., Die Schlacht bei Třebel/ Triebl im Jahr 1647 und weitere Untersuchungen zur Archäologie des Krieges in der Tschechischen Republik. In: Schlachtefelderarchäologie/Battlefield Archeology. 1. Mitteldeutscher Archäologentag vom 09. bis 11. Oktober 2008 in Halle (Saale), Tagungen des Landesmuseums für Vorgeschichte Halle 2 (Meller, H., ed.), 173-186. Halle (Saale).

GROF, V., 2010: Polní opevňovací práce v polovině 19. století, výtah z předpisů pro důstojníky rakouské a pruské armády v polní službě. In: Polní opevnění od třicetileté války do roku 1945. Monumentae vivent (Slavík, J., ed.), 78-97. Jaroměř - Josefov.

HÁJKOVÁ, O.-LOUDA, J., 2013: Polní opevnění z bramborové války na Vrchlabsku dochovaná v terénu, na papíre a v lidové tradici - Feldbefestigungen aus dem „Kartoffelkrieg“ in der Gegend von Vrchlabí, die im Gelände, auf dem Papier und in der Volkstradition erhalten blieben. In: Opevnění. Sborník př́íspěvků z 11. specializované konference stavebně historického průzkumu uspořádané 12.-15. 6. 2012 v Žacléři. Svorník 11 (Kuprová, R.-Buroň, M., edd.), 120-124. Praha.

HAVEL, J., 1980: Hromadný hrob bělohorských bojovníků - Ein Massengrab der krieger vom Weissen Berg / Bílá Hora, Archaeologica Pragensia 1, 227-231.

HEJHAL, P.-HORNÍK, P., v tisku: Polní opevnění z války o bavorské dědictví mezi Třemi Bubny a Jaroměří, AVČ 10.

HOMANN, A., 2013: Battlefield Archaeology of Central Europe - With a Focus on Early Modern Battlefields. In: Historical Archaeology in Central Europe, Society for Historical Archaeology, Special Publication No. 10 (Mehler, N., ed.), 203-230. Rockville.

HORÁČKOVÁ, L.-BENEŠOVÁ, L., 1997: Findings of War-Time Injuries from the Battle of Austerlitz, Anthropologie 35, 283-289.

HORÁČKOVÁ, L.-VARGOVÁ, L., 1999: Bone remains from a Common Grave Pit from the Battle of Austerlitz (Anthropology and Paleopathology), Journal of Paleopathology 11, 5-13.

HORNOFOVÁ, M., 2002: Reflexe třicetileté války v pověstech Plánsko-Bezdružicka. Nepublikovaná diplomová práce, Fakulta humanitních studií, Univerzita Karlova, Praha.

HRNČIŘ́́K, P., 2013: Příspěvek k nálezům munice v prostoru bojiště Rozvadov 1621 - souhrn za období 2010-2012, Tachovský sborník 33, 17-32.

HROCH, M. a kol., 2005: Encyklopedie dějin novověku 1492-1815. Praha.

JANATA, T.-MATOUŠEK, V.-ZIMOVÁ, R., 2013: Historical-cartographic research on battlefields of the Thirty Years' War: the engraving of the siege of Pilsen in 1618, Kartografické listy 21, 18-26.

- 2016: Geospatial Approach to a Thirty-Years-War Military Encampment in Central Moravia Using Iconographic Sources. In: Proceedings of 6th International conference on cartography and GIS (Bandrova, T.Konečný, M., edd.), 90-96. Sofia.

JANSKÁ, E., 1966: Hromadný hrob bělohorských bojovníků - The Collective Grave of White Mountain Fighters. In: Staletá Praha II, 107-110, 306-307. Praha.

KARPIŃSKI, T.-WRZOSEK, J., 2013: Bitwa pod Sarbinowem (Zorndorf), pow. Myśliborski, w świetle badań archeologicznych, Archeologia środkowego Nadodrza X, 113-139.

KODERA, P., 2009: Zaniklá osada Vojkov na Černokostelecku v raně novověkých písemných pramenech, Kuděj - Časopis pro kulturní dějiny 2009/1, 55-62.

KOCH, T., 2014: Jankow 1645. Týnec nad Sázavou.

KOVANDOVÁ, M.-MATOUŠEK, V., 2004: Terénní dokumentace Švédské šance nad hradem Kynžvartem Terraindokumentation der Schwedeneschanze oberhalb der Burg Königswart, Sborník Chebského muzea, 61-66.

KOVÁRNÍK, J. a kol., 2006: Kovárník, J.-Horáčková, L.-Vargová, L.-Mucha, L.-Vachunková, A., Hromadné hroby vojáků na Brněnské ulici z bitvy u Znojma v roce 1809 - Mass Graves of Soldiers in Brněnská Street from the Battle of Znojmo, Ve službách archeologie 7, 313-328.

KRU゚L, M., 2010: Stav výzkumu novověkých opevnění slezsko-uhersko-polské hranice. In: Polní opevnění od třicetileté války do roku 1945. Monumentae vivent (Slavík, J., ed.), 6-18. Jaroměř - Josefov.

- 2013: Stavebněhistorický vývoj jablunkovských šancí - Bauhistorische Entwicklung der Jablunkauer Schanze. In: Sborník příspěvků z 11. specializované konference stavebněhistorického průzkumu uspořádané 12.-15. června 2012 v Žacléři. Svorník 11 (Kuprová, R.-Buroň, M., edd.), 113-119. Praha.

- 2015: Vodovod na Velké šanci v Mostech u Jablunkova - Water Duct to the Great Fort in Mosty u Jablunkova, Těšínsko 58, č. 2, 1-14.

KUBU゚, F.-ZAVŘEL, P., 1988: Pozůstatky valového opevnění rakouské armády v bitvě u Zahájí dne 25. 5. 1742 - Überreste einer Schanzenbefestigung der österreichischen Armee aus der Schacht bei Zahájí am 25. 5. 1742, AVJČ 5, 183-190.

KUNA, M. a kol., 2004: Nedestruktivní archeologie - Non-Destructive Archaeology. Theory, Methods and Goals. Praha.

KUNA, M. a kol., 2014: Archeologický atlas Čech. Vybrané památky od pravěku do 20. století - Archaeological Atlas of Bohemia. Selected Sites from Prehistory to the 20th Century. Praha. 
KUPROVÁ, R.-BUROŇ, M., edd., 2013: Opevnění. Sborník příspěvků z 11. specializované konference stavebně historického průzkumu uspořádané 12.-15. 6. 2012 v Žacléři. Svorník 11. Praha.

LOSKOTOVÁ, I.-HANÁK, V., 1995-1996: Švédský zákop před Brnem, Forum brunense 7, 143-151.

MATOUŠEK, V., 2004: Výstavba modelu polního opevnění z roku 1647 u Olbramova na Tachovsku, (Re)konstrukce a experiment v archeologii. Živá archeologie 5, 260-277.

- 2006: Třebel. Obraz krajiny s bitvou - Třebel. Das Landschaftsbild mit der Schlacht. Praha.

- 2006a: Building a Model of a Field Fortification of the „Thirty Year's War“ near Olbramov, Czech Republic. In: Past Tense. Studies in the Archaeology of Conflict (Pollard, T.-Banks, I., edd.), 115-132. Brill Leiden - Boston.

- 2010: Čechy krásné, Čechy mé. Proměny krajiny Čech v době industriální - Bohemia Beautifull, Bohemia Mine. The Changes of the Bohemian Landscape in the Industrial Age. Praha.

- 2011: Archeologický výzkum novověku a moderní doby v České republice. Několik poznámek k historii, současnému stavu a perspektivám - Modern archaeology formation process in the Czech Lands, Historická sociologie 2, 37-58.

- 2011a: Zpráva o 1. sezoně systematického archeologického výzkumu bojiště z roku 1621 u Rozvadova, Sborník Muzea Českého lesa v Tachově 32, 3-13.

- 2013: Předběžná zpráva o 2. a 3. sezoně archeologického výzkumu bojiště u Rozvadova z roku 1621, Sborník Muzea Českého lesa v Tachově 33, 3-14.

- 2013a: Budování polních opevnění v období třicetileté války. Zkušenosti z archeologických výzkumů na území Čech - Der Bau der feldbefetigungsanlagen in der Zeit der Dreissigjährigen Krieges. Die Erfahrungen aus den archäologischen Grabungen im Gebiet Böhmens. In: Opevnění. Sborník př́íspěvků z 11. specializované konference stavebně historického průzkumu uspořádané 12.-15. 6. 2012 v Žacléři. Svorník 11 (Kuprová, R.-Buroň, M., edd.), 191-200. Praha.

- 2015: Archeologie novověku - univerzální disciplína pro studium třicetileté války, průmyslové revoluce i současné konzumní společnosti? - Archaeology of modern times - a universal discipline for the study of the Thirty Years War, Industrial Revolution and contemporary consumer society? (Some remarks on the interest in archaeology overlapping the Middle Ages), Hospodářské dějiny 28, 67-86.

- 2015a: Poznámky k terénnímu studiu polních opevnění ze 17.-19. století. Zkušenosti z českých zemí Anmerkungen zum terrainstudium der Feldbefestigungen des 17.-19. Jahrhunderts. Erfahrungen aus den Ländern Tschechiens. In: Archeologie opevnění. Konferenční př́ispěvky. Archeologie západních Čech 9 (Šmejda, M., ed.), 70-82. Plzeň.

- 2017: Documentation, recognition and protection of modern field fortifications in the Czech Republic (case study): The Thirty Years' war, International Journal of Heritage Architecture 1-2. Studies, repairs, maintenance 1, 144-152.

MATOUŠEK, V.-BLAŽKOVÁ, T., 2012: The image and reality of battlefields from the Thirty Year's War. A preliminary report on a project for the systematic study of engravings of the battlefields from the Thirty Year's War in the territory of the Czech Republic, Studies in Post-Medieval Archaeology 4, 269-288.

MATOUŠEK, V. a kol., 1990: Matoušek, V.-Hájek, J.-Kubů, Fr.-Meduna, P., A complex investigation of a field fortification of the seven year's war (1756-1763) at the site of Nebesa by Aš (Asch), Studies in Post-Medieval Archaeology 1, 29-66.

MATOUŠEK, V. a kol., 2007: Matoušek, V.-Šimek, J.-Altová, B.-Karlík, P., Pohled na zámek Brandýs nad Labem a opevnění švédského tábora v prostoru Staré Boleslavi z roku 1640 v díle M. Meriana, Historická geografie 34, 93-148.

MATOUŠEK, V.-ZIMOVÁ, R.-JANATA, T., 2012: Optický klam generála Kleinträtla. Rytina bojů u Teplé v záŕi 1647 ve světle mezioborového studia - Visual Trickery of General Kleinträtl. The Engraving of the Battle near Teplá in September 1647 in the Light of Interdisciplinary Studies. In: Krajina jako historické jeviště. K poctě Evy Semotanové (Chodějovská, E.-Šimůnek, R., edd.), 63-80. Praha.

MEDUNA, P., 1990: Morphology of field fortifications of the 17th-19th centuries. A contribution to surface research, Studies in Post-Medieval Archaeology 1, 75-86.

MEHLER, N., 2013: Breaking new Ground: Historical Archaeology in Central Europe. In: Historical Archaeology in Central Europe. Society for Historical Archaeology. Special Publication No. 10 (Mehler, N., ed.), 11-30. Rockville.

- 2011: Vom Little Big Horn bis Lützen - zur Strategie der Schlachtfeldarchäologie in Mitteldeutschland. In: Leben und Sterben auf dem Schlachtfeld von Lützen, beiträge eines wissenschaftlichen Kolloqiums der Schwedischen Lützen - Stiftung Göteborg in Zusammenarbeit mit der Stadt Lützen vom 5. bis 8. November 2009 in Lützen (Reichel, M.-Schuberth, I., edd.), 92-102. Lützen - Göteborg.

MELLER, H., ed., 2009: Schlachtfeldarchäologie. 1. Mitteldeutscher Archäologentag vom 09. bis 11. Oktober in Halle (Saale). Tagung des Landesmuseums für Vorgeschichte Halle 2. Halle (Saale).

MELLER, H.-SCHEFZIK, M., edd., 2015: Krieg. Eine archäologische Spurensuche. Halle (Saale).

MERTLÍK, P., 2013: Stavba pevností v Čechách po sedmileté válce - Festungsbau in Böhmen nach dem Siebenjährigen Krieg. In: Opevnění. Sborník prŕíspěvků z 11. Specializované konference stavebně historic- 
kého průzkumu uspořádané 12.-15. 6. 2012 v Žacléři. Svorník 11 (Kuprová, R.-Buroň, M., edd.), 92-95. Praha.

MEVALDOVÁ, H., 1990: Folk Tales on the Hussars at Nebesa by Aš, Studies in Post-Medieval Archaeology 1, 61-66.

NEJMAN, M., 2010: Popis lokalit s polními fortifikacemi na severním bojišti války o bavorské dědictví zakreslených na mapových listech I. vojenského mapování. In: Polní opevnění od třicetileté války do roku 1945. Monumentae vivent (Slavík, J., ed.), 45-59. Jaroměř - Josefov.

NEUVIRTOVÁ, A., 2010: Identifikace novověkých polních opevnění na území Ústeckého kraje na základě historických map. In: Polní opevnění od třicetileté války do roku 1945. Monumentae vivent (Slavík, J., ed.), 104-106. Jaroměř - Josefov.

NICKLISCH, N. a kol., 2015: Nicklisch, N.-Knipper, C.-Held, P.-Pickard, L.-Ramstahler, F.-Friederich, S.Alt, K. W., Die 47 Soldaten aus dem Massengrab - Ergebnisse der Bioarchäologischen Untersuchungen. In: Krieg. Eine archäologische Spurensuche (Meller, H.-Schefzik, M., edd.), 405-420. Halle (Saale).

PAJER, J., 1990: On the development of a new scientific discipline - post-mediaeval archaeology, Studies in Post-Mediaeval Archeology 1, 23-28.

PERNES, J., a kol., 2003: Pod císařským praporem. Historie habsburské armády 1626-1918. Praha.

POLLARD, T., ed., 2009: Culloden. The History and Archaeology of the Last Clan Battle. Barnsley.

PREUSZ, M. a kol., v tisku: Preusz, M.-Matoušek, V.-Hrnčiřík, P.-Šámal, Z., Zlaté rouno z bronzu. Katolický vojenský prrívěsek z bojiště u Rozvadova/Waidhausu 1621, AZČ.

PROCHÁZKA, Z., ed., 1986: Vojenské dějiny Československa. II. díl (1526-1918). Praha.

RENNER, J., 1912: Srážka u Rakovníka v r. 1620. Věstník Muzejního spolku královského města Rakovníka a politického okresu rakovnického 1 . Rakovník.

RICHTEROVÁ, J., 1981: Německá Lhota, k. o. Kamenné Žehrovice, okr. Kladno. Historie a výzkum, AH 6, 475-479.

- 1982: Geodeticko-topografický průzkum na lokalitě Německá Lhota, okr. Kladno, AH 7, $247-252$.

SIGL, J., 1978: Drobné záchranné výzkumy a průzkumy na území Hradce Králové v letech 1970-1976, Zpravodaj Krajského muzea východních Čech V/1, 55-65.

SCOTT, D.-BABITS, L.-HAECKER, CH., edd., 2007: Fields of Conflict. Battlefield Archaeology from the Roman Empire to the Korean War 1, 2. Westport, Connecticut - London.

SLAVÍK, J., ed., 2010: Polní opevnění od třicetileté války do roku 1945. Monumentae vivent. Jaroměř - Josefov.

SMETÁNKA, Z., 1967: Záchranný výzkum na Bílé hoře - Praha západ, 22. IV. 1955, ulož. v archivu nálezových zpráv ARÚ AV ČR, Praha, v. v. i., čj. 6642/67.

SMRŽ, Z., 2012: Polní opevnění z roku 1813 v trati Mašov (Maschow) na západním okraji Loun. In: Archeologické výzkumy v severozápadních Čechách v letech 2009-2010 (Černá, E. -Kuljavceva-Hlavová, J.-Sýkora, M., edd.), 195-203. Most.

SMRŽ, Z.-HLUŠTÍK, A., 2007: Polní opevnění z roku 1813 mezi Postoloprty a Budyní nad Ohří. Výsledky letecké prospekce a historického bádání - Fieldfortifications dating from 1813 between Postoloprty and Budyně nad Ohří. Results of aerial prospecting and historical research, AR LIX, 713-746.

SYMONDS, J.-VAŘEKA, P., 2016: Paysans et soldats. Archaeologie des villages de Boheme abandonnes durant la guerre de trente Ans. In: Violences de Guerre, violences de masse (Guilaine, J.-Semelin, J., edd.), 129-145. Paris.

ŠÁMAL, Z., 2011: Archeologové na bojišti (Několik poznámek k detektorovému průzkumu rakovnického bojiště z roku 1620). In: Bitva u Rakovníka 1620 (Blažková, K., ed.), 50-59. Rakovník.

ŠMEJDA, M., ed., 2015: Archeologie opevnění. Konferenční př́íspěvky, AZČ 9, 5-82.

VAŘEKA, P., 2009: Zaniklá středověká vesnice Vojkov na Černokostelecku - svědectví archeologie, Kuděj Časopis pro kulturní dějiny 2009/1, 43-54.

- 2014: Zaniklá středověká a časně novověká ves na Zbirožsku, AZČ 7, 131-143.

VAŘEKA, P. a kol., 2006: Archeologie zaniklých středověkých vesnic na Rokycansku I - Archaeology of deserted medieval villages in Rokycany region I. Plzeň.

WALDHAUSER, J., 2009: Švédský vojenský tábor ze třicetileté války na katastrech Staré Boleslavi (okr. Praha-východ) a Hlavence (okr. Mladá Boleslav) - Das schwedische Militärläger aus dem Dreissigjährigen Krieg im Raum von Katastern Stará Boleslav (Bez. Prag-Ost) und Hlavenec (Bez. Mladá Boleslav), ASČ 13, 939-964.

ZUMAN, F., 1931: Švédský tábor ve Staré Boleslavi, Ročenka okresní jednoty musejní v Brandýse n. L., 5-17.

ŽEGKLITZ, J., 2013: Archaeology of the Modern Period in the Czech Territories: A Long Tradition and Long Beginnings. In: Historical Archaeology in Central Europe. Society for Historical Archaeology. Special Publication No. 10 (Mehler, N., ed.), 53-69. Rockville. 


\section{Zusammenfassung}

\section{Die archäologische Erforschung von Schlachtfeldern und des Militärwesens des frühen Mittelalters in den Ländern Böhmens. Geschichte, Kenntnisstand, Diskussionen}

Die Archäologie des Militärwesens (vor allem die archäologische Erforschung von Schlachtfeldern, Feldbefestigungen und Festungssystemen) ist was die böhmischen Länder betrifft eine der am gründlichsten ausgearbeiteten Subdisziplinen der Archäologie der Neuzeit (zur Geschichte der Archäologie der Neuzeit in den Ländern Böhmes allgemein zuletzt Žegklitz 2013). Bereits im Jahr 1912 wurden die Ergebnisse einer Geländeuntersuchung auf einem Schlachtfeld aus dem Jahr 1620 bei Rakovník veröffentlicht (Renner 1912). Einen qualitativen Schub in der Entwicklung der Disziplin beobachten wir ab dem Anfang der achtziger Jahre des 20. Jahrhunderts, als eine Serie systematischer, komplex und interdisziplinär angelegter Untersuchungen von neuzeitlichen Schlachtfeldern ihren Anfang nahm: ein Schlachtfeld aus dem Jahr 1759 in Nebesa bei Aš (Matoušek et al. 1990), ein Schlachtfeld aus dem Jahr 1647 unterhalb von Burg Třebel (Triebel) in der Region Tachov (Matoušek 2006a), ein Schlachtfeld aus dem Jahr 1621 zwischen Rozvadov und Waidhausen (Altová et al. 2008; Matoušek 2011b; 2013a; Preusz et al. im Druck) und ein Schlachtfeld aus dem Jahr 1620 bei Rakovník (Blažková 2011).

Darüberhinaus erfolgt seit 2005 eine systematische Erforschung der Feldbesfestigungssysteme an der schlesisch-ungarisch-polnischen Grenze (zuletzt Krůl 2015). Eine weiteres wichtiges, lang angelegtes und interdisziplinäres Projekt ist das Studium der Kupferstiche mit den Schlachtfeldern des Dreißigjährigen Kriegs in den Länder Böhmens im Werk von M. Merian (vorläufig zusammengefasst von Matoušek-Blažková 2012; in den letzten Jahren wurde die Forschung um die Zusammenarbeit mit Geodäten und Kartografen bereichert - Matoušek-Zimová-Janata 2012; Janata-Matoušek-Zimová 2013; Janata-Matoušek-Zimová 2016).

Ein weiterer, relativ selbständiger Themenkreis des Studiums neuzeitlicher Schlachtfelder, besonders der Schlachtfelder des Dreißigjährigen Krieges, sind Fragen zum Militärbauwesen im Feld. Konkret die Morphologie von Befestigungen, ihre Konstruktion und die Problematik ihrer Archäologisierung (dazu zusammenfassend Matoušek 2013b; 2015b; 2017). Zu diesem Thema des neuzeitlichen Bauwesens wurde eine Serie spezialisierter, interdisziplinärer Fachbegegnungen veranstaltet (Slavík ed. 2010; Kuprová-Buroň edd. 2013; Šmejda ed. 2015).

Der Lehrstuhl für Archäologie der Westböhmischen Universität in Pilsen konzentriert sich langfristig und systematisch auf das Geländestudium der Auswirkungen der Ereignisse des DreiBigjährigen Krieges auf die ländliche Besiedelung (zuletzt Vařeka 2014; Symonds-Vařeka 2016).

Beim Studium der Schlachtfelder erfolgt seit den achtziger Jahren eine systematische Untersuchung mithilfe von Metalldetektoren. Die wichtigsten Ergebnisse erbrachte bislang das Studium des Schlachtfeldes aus dem Jahr 1620 bei Rakovník (Šámal 2011) und des Schlachtfeldes aus dem Jahr 1621 bei Rozvadov (Hrnčiřík 2013). Bei der Suche und Dokumentation von Feldbefestigungen werden in erheblichem Maße die Methoden zur Fernuntersuchung der Erde angewandt: Luftaufnahmen und Laserscanning /LIDAR (zusammengefasst von Gojda 2013). Umgekehrt nur eine marginale Anwendung finden bislang die Methoden der experimentellen Archäologie (Matoušek 2006b). Auch die Intensität der Zusammenarbeit zwischen Archäologen und Historikern ist bislang nicht zufriedenstellend (detailliert zur Archäologie des Militärwesens des Mittelalters und der Neuzeit in den Ländern Böhmens Grabolle et al. 2009).

Die vorliegende Studie entstand im Rahmen des Förderprojektes „Verwandeltes Land: interdisziplinäre Erforschung des Einflusses des Dreißigjährigen Krieges auf die ländlichen Gebiete Böhmens“, GAČR 15-03380S.

Prof. PhDr. Václav Matoušek, CSc., Katedra sociální a kulturní ekologie Fakulty humanitních studií Univerzity Karlovy, U Kř́iže 8/661, 15800 Praha 5 - Jinonice, Česká republika, vaclav.matousek@fhs.cuni.cz 
